\title{
Improving chemical and hydro-physical properties of semi-arid soils using different magnitudes of crumb rubber
}

\author{
Vahideh Sadeghizadeh ${ }^{1} \cdot$ Vahidreza Jalali $^{1}$ (D)
}

Received: 6 April 2017/Accepted: 3 August 2017/Published online: 8 August 2017

(c) The Author(s) 2017. This article is an open access publication

\begin{abstract}
Purpose Iran is located on the desertification strip where it has faced water shortage and poor quality soils. So it is necessary to improve the soil structure and increase irrigation efficiency. In this context, the use of industrial wastes can increase soil's organic matter and improve its structure, also amend environmental problems related to disposal of industrial wastes. The objective of this study was to survey the effect of crumb rubber (CR) application as soil amendment on soil water retention curve indices, soil aggregate stability and soil micronutrients.

Methods In this study, different amounts of CR (0, 0.12, $0.24,0.36$ and $0.48 \mathrm{~g}$ ) were added to every $\mathrm{kg}$ of the two different soil textures (loamy sand and silty clay). Pots were kept at FC moisture conditions for 6 months. At the end of incubation time, the different soil micronutrient availability, soil structural stability and soil hydraulic properties were measured.

Results The results showed that application of $\mathrm{CR}$ as soil amendment had significant effects $(p<0.001)$ on increasing soil organic matter content and soil micronutrient availability including $\mathrm{Zn}$ and $\mathrm{Fe}$. Adding $\mathrm{CR}$ particles by reducing the aggregate fractal dimension, soil penetration resistance and bulk density, improves soil structure in both types of soil. The results also demonstrated that the use of $\mathrm{CR}$ particles can improve water
\end{abstract}

Vahidreza Jalali

V.Jalali@uk.ac.ir

Vahideh Sadeghizadeh

sadeghizadevahideh@yahoo.com

1 Department of Soil Science, Faculty of Agriculture, Shahid Bahonar University of Kerman, Kerman, Iran holding capacity in sandy soil and increased plant available water content and air capacity in clay soil $(p<0.001)$. Conclusions According to our results adding CR particles can be considered as a low-cost solution in order to improve the hydro-physical and chemical properties of soils in these areas.

Keywords Aggregate stability - Crumb rubber .

Penetration resistance $\cdot$ Plant available water content $\cdot$ Soil water retention curve

\section{Introduction}

Soil properties are the crucial factors for crop production (Dotaniya et al. 2016). Soils in arid and semi-arid regions are often characterized by low clay and organic matter contents which results in low water holding capacity and inherently low fertility (Abdelfattah 2013). In order to improve soil structure and to increase under cultivation areas in arid and semi-arid regions, there are various management methods such as adding soil amendments, mulches and conservation tillage (Roper et al. 2013; Zhao et al. 2011; Bhatt et al. 2016).

Saline and sodic soils in arid and semi-arid areas cause unfavourable soil physical and chemical properties, which would impose restrictions on plant growth (Jalali et al. 2017). So the applications of appropriate soil amendments result in improving soil properties and reduced soil salinity and other stresses (Courtney and Harrington 2012; Bhattacharjya et al. 2016).

Different synthetic polymers are used for soil amendments in the agriculture which are safe and non-toxic and will eventually decompose to carbon dioxide, water, ammonia and potassium ions. Applying water-absorbing 
soil amendment may improve soil structure, arise water storage and decrease other water-related limitations (Huettermann et al. 2009).

Due to shortage of natural organic matters in arid and semi-arid regions, the use of organic polymers to improve soil structure was very important over the past years and these polymers have shown their ability as soil amendments. In fact, soil management practices encourage the addition of organic matter to the soil which has significant effect on soil physical and chemical properties (Weyers and Spokas 2014).

Previous studies demonstrated positive changes in several soil physical, chemical and biological properties after the addition of organic amendments to soil (Faust et al. 2015; Pandian et al. 2016; Adrover et al. 2017). The improvement of crop productivity has been attributed to the increase in the soil available nutrients (Lia et al. 2017; Chaudhuri et al. 2016; Rajaie and Tavakoly 2016) and enhanced soil physical properties such as reduction in soil bulk density and soil penetration resistance (Saglam and Dengiz 2017) and increase in water-holding capacity after applying soil amendments (Emami et al. 2014; Parihara et al. 2016).

Unfortunately, in some arid and semi-arid areas, natural organic matter is either unavailable or scarce; as an example more than 70 percent of Iran's agricultural soil contains less than 0.5 percent organic matters and ingredient (FAO 2012); thus, improvement of soil structure may be achieved using synthetic polymers (Masowa et al. 2016; Park et al. 2015).

Of the annual total global production of rubber material, which amounts to more than 10 million tons, approximately $60-70 \%$ is used in tyre. After they have been wornout during their limited service life, millions of used tyres are discarded every year. As polymeric materials, rubbers do not decompose easily. Large amounts of waste rubber materials discarded pose two major problems: waste of valuable rubber and disposal of waste rubber leading to environmental pollution. Two major ways to solve the problem are recycling and reusing the waste rubber and reclaiming rubber's raw materials (Zhao et al. 2009).

Crumb rubber (CR) is a secondary resource recycled from scrap automobile tires. This amendment contains graded rubber granules and sometimes additional components, such as compost or mineral materials. The Application of waste polymer such as CR into soil behaves as reinforcement factor in improving soil function. Applying waste plastic for reinforcement of soil is an efficient and reliable technique for improving the strength and stability of soils (Sivakumar Babu et al. 2008). In this area, the amount and size of CR are the most effective factors which determine the soil structure stability from both agriculture and engineering point of view.
$\mathrm{CR}$ is not truly inorganic; it behaves much in the same way. Amendments with coarse grade $\mathrm{CR}$ can reduce compaction stress in soil, increase total porosity and enhance water movement. Finer particle sizes are being used for topdressing and can protect the crown tissue of plants from abrasion (Groenevelt and Grunthal, 1998). Vanini and Rogers (1995), used the rubber crumb as a soil amendment in different turfgrass situations.

Groenevelt and Grunthal (1998) pointed out that 10-20\% of CR significantly reduced surface hardness of sports turf. Riggle (1994) also stated that the inclusion of rubber particles in soil could improve soil physical properties such as aeration and water infiltration rates. He concluded that the water use efficiency and fertilizers were improved by up to $30 \%$. Intention to reuse the abandoned tires by grinding them into small particles (crumb rubber) and using them in sports field, pavement and construction materials may be an important approach to reduce waste rubbers in large quantities (Yilmaz and Degirmenci 2009).

Zhao et al. (2011) investigated the effect of CR waste as a soil conditioner on the nematode assemblage and some soil properties in a turfgrass soil. Their results demonstrated that CR incorporation significantly decreased plant parasite and omnivorous nematode populations, but increased the abundance of predatory nematodes, and also $\mathrm{CR}$ application decreased soil bulk density and $\mathrm{pH}$ value, while soil moisture content increased.

Taheri et al. (2011) reported that ground tyre rubber and rubber ash were very effective amendments to increase the DTPA-extractable $\mathrm{Zn}$ in a calcareous $\mathrm{Zn}$-deficient soil. Khoshgoftarmanesh et al. (2012) investigated the effect of acid-washed shredded waste-tire rubber in hydroponic tomato production. They said shredded waste rubber might be used as a component of container media in production of hydroponically grown tomato; however, acid-washing of rubber is required to prevent potential $\mathrm{Zn}$ toxicity for plant.

Pérez et al. (2012) investigated the use of rubber crumbs as drainage layer in green roof establishment. The results of their research raised the possibility of using recycled rubber from tires as a drainage layer in green roofs, substituting the porous stone materials currently used.

Several studies have been carried out throughout the world to identify the effects of incorporating different soil amendment and organic matter into soil and survey their effect on soil's physical and chemical properties. However, various potential use of CR and its environmental impacts have been less investigated and there have been no published investigations about using CR effects on some soil's physical and chemical properties in arid and semiarid region soils. Therefore, the objective of this study was to assess the impacts of waste CR as soil amendment on the soil hydro-physical and chemical properties in arid and semiarid soils. The investigations may provide a basis for 
mitigating the worn out tires' pollution problems in the environment, while enhancing some soil's chemical and hydro-physical properties of semi-arid soils.

\section{Materials and methods}

\section{The study site and soil properties}

This study was carried out in the research greenhouse of the Shahid Bahonar University of Kerman, southeast of Iran (latitude of $30^{\circ} 14^{\prime} \mathrm{N}$ and longitude of $57^{\circ} 06^{\prime} \mathrm{E}$ ). Kerman and the surrounding regions have a semi-moderate and dry climate with mean annual rainfall of $153 \mathrm{~mm}$ (Yazdanpanah et al. 2016). Two different soil textures [loamy sand $(S)$ and silty clay $(C)$ ], were collected and air-dried and passed through a $2-\mathrm{mm}$ sieve and stored at room temperature before use.

Physical and chemical properties of the soil samples were quantified in our laboratory. Soil particle size distribution was determined using the hydrometer method (Gee and Bauder 1986), and organic carbon (OC) was measured using the wet-digestion method (Walkley and Black 1934). Soil electrical conductivity $(\mathrm{EC})$ and reaction $(\mathrm{pH})$ were determined in a soil-water extract of 1:5 w:v.

EDTA-extractable elements ( $\mathrm{Zn}, \mathrm{Fe}$ and $\mathrm{Cu}$ ) were determined by atomic absorption spectrometry (AAS) (Quevauviller et al. 1996) and bulk density was determined with core sample (Blake and Hartge 1986), respectively. The properties of CR particles (with a diameter of less than $2 \mathrm{~mm}$ ) used in these experiments are presented in Table 1 (Asadollah zadeh 2013). The cation exchange capacity (CEC) of used CR particles was reported about $57 \mathrm{cmol}^{+} \mathrm{kg}^{-}$(Khoshgoftarmanesh et al. 2012).

\section{Preparation of test pots}

In this study, the pots with a capacity of $6 \mathrm{~kg}$ were used. The test substrates were prepared by adding $0,0.12,0.24$, 0.36 and $0.48 \mathrm{~g} \mathrm{CR}$ (with a diameter of less than $2 \mathrm{~mm}$ ) to every $\mathrm{kg}$ of the two different soil textures. The soil and CR were manually blended and transferred to close-end pots without drainage. The pots were stored at greenhouse temperature conditions $\left(23 \pm 2{ }^{\circ} \mathrm{C}\right)$ and humidity of field capacity for 6 months before being used to prepare the test samples. Depending on the soil type, specific climate conditions and Intended land-use, different researchers have reported different incubation period from at least
3 months (Zhao et al. 2011), 8 months (Bidaki et al. 2012) and 11 months (Smolders and Degryse 2002), so in this study, the mean of the periods reported (6 months) were selected as the incubation period.

\section{Measuring soil physical properties}

\section{Penetration resistance $(P R)$}

Penetration resistance (PR) is a suitable indicator for identifying changes in soil resistance to penetration over a period and for assessing the effects of soil resistance to root development (O'Sullivan 1992). After incubation time, at the end of the test, the samples were irrigated to field capacity water content, and penetration resistance of the samples was determined by penetrometer device (33T0165 model, CONTROLS Inc).

Depending on the type of soil texture, 0.2 square inch metal cap was used for loamy sand $(S)$ and 0.1 square inch metal cap were used for silty clay $(C)$ samples. Penetrometer probe was immersed to a certain extent (depth of $3 \mathrm{~cm})$ at a nearly constant speed in soil samples. Soil penetration resistance was calculated using the function employed by Tormena et al. (1999) as:

$\mathrm{PR}=\frac{0.5 X}{Y} \times \alpha$,

where PR is the soil penetration resistance (MPa), $X$ is registered device number ( $\mathrm{mm}), Y$ is cross-sectional area of used metal cap (square inch) and $\alpha$ is acceleration gravity $\left(9.8 \mathrm{~ms}^{-2}\right)$.

\section{Soil aggregate stability}

Soil aggregate stability was determined by mean weight diameter index (MWD) and Fractal dimension by using Eqs. 2 and 3 (Calero et al. 2008).

$\mathrm{MWD}=\sum_{i=1}^{n} x_{i} w_{i}$

where $X_{i}$ is the mean diameter of any particular size range of aggregates separated by sieving $(\mathrm{mm})$, and $W_{i}$ is the weight of the aggregates in that size range as a fraction of the total dry weight of the sample. The summation accounts for all size ranges, including the group of aggregates smaller than the openings of the finest sieve.
Table 1 Selected physical and chemical properties of crumb rubber $(\mathrm{CR})$ particles

\begin{tabular}{lllllll}
\hline $\mathrm{EC}\left(\mathrm{dS} \mathrm{m}^{-1}\right)$ & $\mathrm{pH}(-)$ & $\mathrm{Zn}\left(\mathrm{mg} \mathrm{kg}^{-1}\right)$ & $\mathrm{Fe}\left(\mathrm{mg} \mathrm{kg}^{-1}\right)$ & $\mathrm{Cu}\left(\mathrm{mg} \mathrm{kg}^{-1}\right)$ & ${\mathrm{Cd}\left(\mathrm{mg} \mathrm{kg}^{-1}\right)}_{\rho_{\mathrm{b}}\left(\mathrm{g} \mathrm{cm}^{-3}\right)}$ \\
\hline 0.354 & 6.82 & 12,000 & 108 & 4.25 & 2.25 & 0.2 \\
\hline
\end{tabular}


Fractal dimension index of soil aggregates was calculated based on the size-number equation of Turcotte (1989) as follows:

$N_{i}=c X_{i}^{-D}$

where $X_{i}$ is the mean diameter of remaining aggregates on each sieve $(\mathrm{mm})$ and $c$ is constant coefficient. Fractal dimension $(D)$ was obtained through regression analysis between $\log N_{i}$ and $\log X_{i}$. The amount of $N_{i}$ is determined from stable aggregate distribution and it will be determined at the end of sieving as follows (Eq. 4 and 5):

$N_{i}=\sum_{\mathrm{i}=1}^{n} n_{\mathrm{i}}$

$n_{i}=w_{i} \rho^{-1} \times x_{i} \rho^{-3}$,

where $n_{i}, \rho$ and $w_{i}$ are the number of aggregates, aggregate bulk density and the remaining aggregate mass on each sieves, respectively.

\section{Soil hydraulic properties}

Water retention curve is one of the main soil hydraulic properties. It can be considered as a soil's fingerprint, since the shape of the curve is related to various physical and chemical soil properties, which are unique for each soil (Cornelis et al. 2001). Therefore, any change in soil structure will appear in soil water retention curve. In this research, the widely used model of van Genuchten (1980) was fitted to the data obtained from pressure plate apparatus.

Different physical quality indicators derived from water retention curve have been proposed and validated by several authors. Reynolds et al. (2007) found that air capacity (AC) and relative water capacity (RWC) could be good indicators because they responded to different soil management practice, so in this research air capacity, relative water capacity and plant available water capacity (PAWC) were considered.

According to Reynolds et al. (2007), AC is the difference between saturation water content and water content at field capacity (FC). PAWC is the difference between FC and permanent wilting point (PWP). RWC is the ratio of water content at $\mathrm{FC}$ to water content at saturation.

\section{Statistical analyses}

Current research was carried out with five different $\mathrm{CR}$ application rates $\left(0,0.12,0.24,0.36\right.$ and $\left.0.48 \mathrm{~g} \mathrm{~kg}^{-1}\right)$ for two texturally differentiated soil which were named $C_{0}$, $C_{0.12}, C_{0.24}, C_{0.36}$ and $C_{0.48}$ for silty clay soil and $S_{0}, S_{0.12}$, $S_{0.24}, S_{0.36}$ and $S_{0.48}$ for loamy sand $(S)$. These pots were arranged in a randomized complete block design with three replicates.

Statistical assessments of possible difference in soil's physical and chemical properties due to the five rates of CR treatment were analysed with one way-ANOVA by using the SAS program (SAS Institute 1996). Duncan's multiple range test was used to compute LSD values for comparing differences between pairs of treatment means

\section{Results and discussion}

\section{Amending the soil chemical properties with CR}

\section{Electrical conductivity $(E C)$ and soil reaction $(p H)$}

Table 2 shows physical and chemical properties of the studied soils. Statistical analyses of CR particles' addition on soil physical and chemical properties are presented in Table 3. Based on the data presented in this table, it becomes clear that increasing different amounts of CR has not significantly affected the EC and $\mathrm{pH}$ of both types of soil in this limited period of incubation.

Considering the table, it is uncovered that with expanding the utilization of $\mathrm{CR}$, the electrical conductivity of loamy sand soil has slight expanding pattern while this pattern has been declining in silty clay soil. On the other hand, increasing the amount of CR, increased and decreased the salinity in the loamy sand and silty clay soils, respectively, but as mentioned this slight changes were not statistically significant.

$\mathrm{pH}$ changes were quite different in both types of soils so that, by increasing the amount of crumb rubber, loamy sand soil's $\mathrm{pH}$ value decreases, whereas silty clay soil's $\mathrm{pH}$ was increased.

As previously mentioned, the main feature of CR particles is their low biodegradability and long-term effectiveness in soil. So no statistically significant effect of these treatments on a limited time scale seems quite logical. Due to the abundance of lime in semi-arid soils, (such as Kerman-Iran), overcoming buffering capacity and changing chemical properties of these soils needs more incubation time.

\section{Organic carbon content $(O C)$}

$\mathrm{CR}$ is a complex vulcanized elastic which is essentially involved natural rubber (NR), like polyisoperene, and synthetic elastic (SR), like styrene-butadiene elastic as well as butadiene elastic, which are cross connected with sulphur and fortified with carbon dark (CB) (Ghavibazoo and Abdelrahman 2013). Najim and Hall (2012) reported that $\mathrm{CR}$ had at least 28 percent of carbon dark by weight. So as 
Table 2 Selected physical and chemical properties of the studied soils

\begin{tabular}{lcccccccccc}
\hline Texture & Sand(\%) & $\begin{array}{l}\text { Silt } \\
(\%)\end{array}$ & $\begin{array}{l}\text { Clay } \\
(\%)\end{array}$ & $\begin{array}{l}\mathrm{O} . \mathrm{C} \\
(\%)\end{array}$ & $\begin{array}{l}\mathrm{EC} \\
\left.(\mathrm{dS} \mathrm{m})^{-1}\right)\end{array}$ & $\mathrm{pH}(-)$ & $\begin{array}{l}\mathrm{Zn} \\
\left(\mathrm{mg} \mathrm{kg}^{-1}\right)\end{array}$ & $\begin{array}{l}\mathrm{Fe} \\
\left(\mathrm{mg} \mathrm{kg}^{-1}\right)\end{array}$ & $\begin{array}{l}\mathrm{Cu} \\
\left(\mathrm{mg} \mathrm{kg}^{-1}\right)\end{array}$ & $\begin{array}{l}\rho_{\mathrm{b}} \\
\left(\mathrm{gr} \mathrm{cm}^{-3}\right)\end{array}$ \\
\hline $\begin{array}{c}\text { Loamy } \\
\text { sand }\end{array}$ & 85 & 4 & 11 & 0.0 & 1.37 & 7.5 & 1.33 & 3.22 & 0.32 & 1.64 \\
\begin{tabular}{l} 
Silty clay \\
\hline
\end{tabular} & 3 & 42 & 55 & 0.01 & 1.16 & 7.9 & 0.92 & 4.83 & 0.84 & 1.45 \\
\hline
\end{tabular}

expected, the addition of CR significantly increased the organic carbon content (OC) in both soils. Since the soil's organic carbon content is very small in the control sample of both soils, then increase in OC, was highly significant $(p<0.001)$ when the CR amount was increased in two soils (Table 3 ).

For loamy sand soil, organic carbon content from about zero percent (in control) was increased to $1.4 \%$ in the $S_{0.48}$ treatment. While in the silty clay soil due to weaker aeration, organic carbon content in highest $\mathrm{CR}$ application rate $\left(C_{0.48}\right)$, reached to $2.1 \%$.

Considering these results, it can be concluded that in areas where natural organic material is not available, addition of CR particles can be the convenient, inexpensive and a fast solution to improve soil organic carbon content.

\section{Micronutrient availability}

The investigation results indicated that using $\mathrm{CR}$ as soil modification had significant effect on the soil micronutrient such as Fe and $\mathrm{Zn}$, but at different $\mathrm{CR}$ application rate, the copper content is not significantly changed (Table 3 ).

In the loamy sand substrate, the concentration of zinc increased significantly $(p<0.001)$, when the amount of CR was increased to $0.24 \mathrm{~g} \mathrm{~kg}^{-1}$ and in higher application values $\left(S_{0.36}\right.$ and $\left.S_{0.48}\right)$, despite slight increases in zinc content, these changes were not statistically significant. Also in these substrates, the concentration of Fe increased $(p<0.001)$, when the added CR was $0.36 \mathrm{~g} \mathrm{~kg}^{-1}$ and between $S_{0.36}$ and $S_{0.48}$ treatments, significant changes were not seen (Table 3 ).

For silty clay soil, increasing the concentration of applied CR has a significant effect on all treatments, so that the $\mathrm{Zn}$ content in control treatment $\left(0.91 \mathrm{mg} \mathrm{kg}^{-1}\right)$ has increased up to $17.97 \mathrm{mg} \mathrm{kg}^{-1}$ in $C_{0.48}$ treatment. In the case of Fe for silty clay soil, there was significant difference between the lowest and highest CR application value with control. Increasing $\mathrm{Zn}$ content by increasing the $\mathrm{CR}$ application rate can be attributed to pure $\mathrm{Zn}$-Oxide which was used in tyre production process. This results demonstrated that these findings are in perfect agreement with Taheri et al. (2011) which said CR and rubber ash were very effective in improving DTPA-extractable $\mathrm{Zn}$ in a calcareous Zn-insufficient soil.
Unlike the iron and zinc elements, increasing the application of CR in different amounts had no significant effect on increasing copper content in all treatments. The main reason for this can be attributed that copper unlike iron and zinc, not involved directly in the tires production process.

However, in calcareous soils, such as our research soils, due to the stabilization of metal elements such as zinc in top soil, there are little concerns regarding contamination of these elements, but by reducing the soil's $\mathrm{pH}$ and in acidic soils, due to the abundance of zinc in CR, application of this modifier should be used with caution.

\section{Effect of CR amendment on soil physical properties}

\section{Bulk density (BD)}

The mean comparison results of different CR application rate indicated that the application of $\mathrm{CR}$ cause significant decrease of soil bulk density (BD) in both soils.

In loamy sand soil, soil bulk density was decreased significantly $(p<0.001)$ from $1.64 \mathrm{~g} \mathrm{~cm}^{-3}$ in control treatment to $1.40 \mathrm{~g} \mathrm{~cm}^{-3}$ by addition of $0.48 \mathrm{~g} \mathrm{~kg}^{-3} \mathrm{CR}$ to the soil and also for silty clay soil, bulk density was reduced significantly $(p<0.05)$ from $1.44 \mathrm{~g} \mathrm{~cm}^{-3}$ in the control to $1.28 \mathrm{~g} \mathrm{~cm}^{-3}$ in the $0.48 \mathrm{~g} \mathrm{~kg}^{-3} \mathrm{CR}$ treatment (Table 3). These results are consistent with the findings of Zhao et al. (2011) who said that CR application decreased soil bulk density in a sand-based medium.

Porous structure in tyres causes a significant reduction in both soil bulk densities. This property of CR has potential for usage in environments that have high traffic and have been subjected to density increases.

\section{Mean weight diameter (MWD)}

Based on the results presented in Table 3, the application of different amount of CR had significant effect on soil aggregate mean weight diameter (MWD). Duncan's multiple range test was employed for mean comparison of the different CR levels on aggregate MWD (Table 3). Considering mean comparison data in Table 3 , the addition of CR significantly increased the MWD in both soils. In loamy sand soil, MWD increased significantly $(p<0.001)$ 


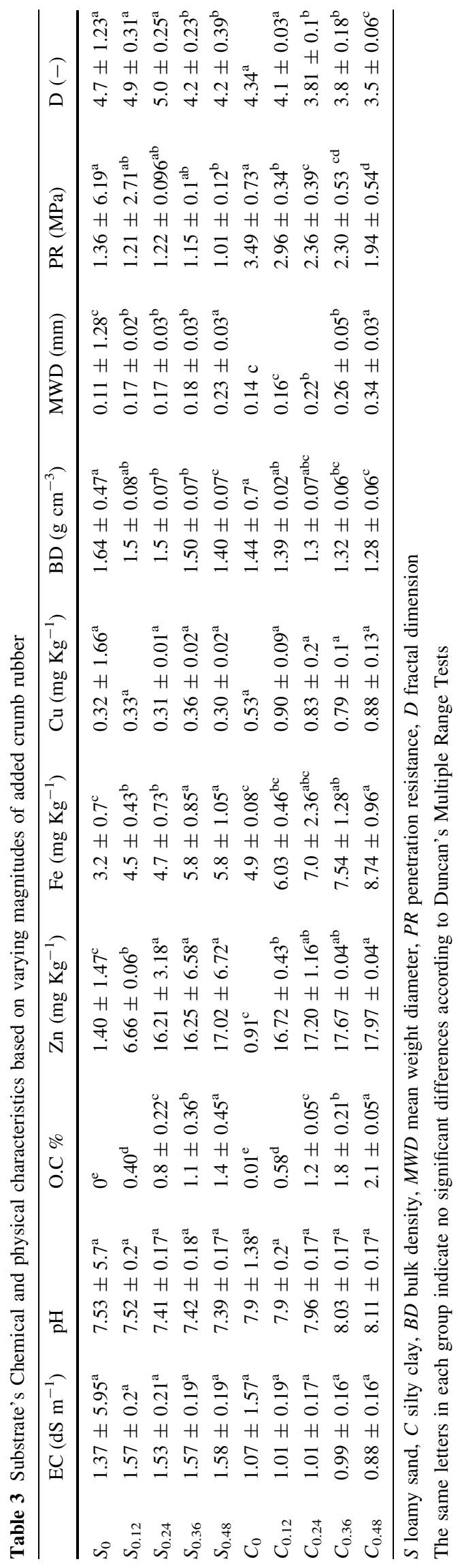


from $0.11 \mathrm{~mm}$ in control treatment to $0.23 \mathrm{~mm}$ at highest CR level $\left(S_{0.48}\right)$. Also for silty clay soil, MWD was increased significantly $(p<0.001)$ from $0.14 \mathrm{~mm}$ in control treatment to $0.34 \mathrm{~mm}$ in the $0.48 \mathrm{~g} \mathrm{~kg}^{-1} \mathrm{CR}$ treatment $\left(C_{0.48}\right)$. These finding is strong evidence that the CR application in soil through its effect on SOC increased MWD significantly. The strong correlation between MWD and SOC were reported by different researchers around the world. Chaney and Shift (1984) revealed a direct relationship between aggregate stability and SOC content in 120 soils gathered from various soil arrangement in Scotland and England. Similarly, Nyamangara et al. (2001) detailed that a 10-38\% addition in soil organic carbon with yearly utilization of cows compost at a rate of 12.5 $\mathrm{Mg} \mathrm{ha}^{-1}$ for a long time brought about three to fourfold increment in soil MWD in a granitic sandy soil in Zimbabwe.

\section{Fractal dimension (D)}

There are many methods to describe the aggregate stability which the important ones include several sieving methods leading to mean weight diameter (MWD), geometric weight diameter (GMD) and in the last few decades fractal dimension index $(D)$. These have been used to describe aggregate stability. In this research, the soil aggregate's fractal dimension was obtained from dry sieving data and using the formulas 3 and 4. The addition of CR significantly decreased $(p<0.001)$ the $\mathrm{D}$ in loamy sand soil when the amount of CR was increased up to $0.36 \mathrm{~g} \mathrm{~kg}^{-1}$, whereas in silty clay substrate, the decrease in the $D$ with increasing rate of amendment was significant $(p<0.001)$ when the $\mathrm{CR}$ amount reached to $0.48 \mathrm{~g} \mathrm{~kg}^{-1}$. As it is clear from these findings, aggregate's fractal dimension $(D)$ has inverse proportionality with mean weight diameter, significantly decreasing the fractal dimension of different treatments related to improving soil structure at various level of CR application.

\section{Penetrometer resistance $(P R)$}

One of the negative effects of the lack of organic matter in arid and semi-arid soils, like Iran, is increasing soil penetration resistance which is caused by weak soil structure.

High penetration resistance in these soils imposes restrictions during soil tillage and plowing, water infiltration into the soil, soil respiration and seed germination. This research revealed that the addition of CR significantly decreased soil penetration resistance in both types of soils.

In loamy sand soil, penetration resistance was decreased from $1.36 \mathrm{MPa}$ in control to $1.01 \mathrm{MPa}$ in $S_{0.48}$ treatment. While this decline rate was higher in silty clay soil, so that the control penetration resistance was $3.49 \mathrm{MPa}$,it decreased significantly to $1.94 \mathrm{MPa}$ in $C_{0.48}$ treatment. These results are consistent with the findings of Groenevelt and Grunthal (1998) who said that an increase of 10-20\% of CR fundamentally decreases surface hardness of games turf.

\section{Effect of CR amendment on soil hydraulic properties}

One of the most important ways to deal with water shortage in arid and semi-arid regions is adding amendments to soil in order to increase water use efficiency and improve the physical properties of these soils. The non-linear relationship between soil water content $\left(\theta_{\mathrm{V}}\right)$ and its matric potential $\left(\psi_{\mathrm{m}}\right)$ called soil water characteristic curve (SWCC) which expresses the effect of soil structure, total porosity and pore size distribution on soil water availability.

By studying the soil moisture characteristic curve at the difference treatment levels $(0.12,0.24,0.36$ and $0.48 \mathrm{~g}$ of crumb rubber $/ \mathrm{kg}$ soil), it was revealed that by addition of $\mathrm{CR}$ application rate, water content increased at each suction point in both types of soils and maximum water content was gained at highest application rate of $\mathrm{CR}$ (0.48 $\mathrm{g} \mathrm{kg}^{-1}$ ) (Fig. 1).

Observing the overall considering of SWCC in low suction points $(1,100$ and $330 \mathrm{~cm})$ and high suction points (5000-15,000 cm) range, it can be concluded that significant amount of moisture absorbed by the CR particle is released in low suction points, so the release of moisture in low suction point is considered as an advantage for using $\mathrm{CR}$, especially in moderate to heavy textural soils. Comparison of residual water content at high suction points (5000-15,000 cm) showed that the residual water content in the rubber-amended soil was also significant, especially at high levels of $\mathrm{CR}$ application. The reasons for the increase of moisture in the treatments containing CR can be attributed to increasing porosity, decreasing density and increasing surface area of rubber-amended soils. In this area, Riggle (1994) expressed that incorporating rubber particles in soil could enhance the water use efficiency by up to $30 \%$. In general, polymers due to their hydrophilic properties are effective in improving soil properties especially in increasing soil moisture content.

\section{Effect of CR amendment on soil water retention curve parameters}

\section{Plant available water content (PAWC)}

Routinely, plant-available water content (PAWC) is obtained by subtracting moisture at field capacity and permanent wilting point. Based on the results as given in Table 4 , CR particles significantly $(p<0.001)$ increased 
Fig. 1 Soil retention curves of silty clay (a) and loamy sand (b) soils as affected by different CR level

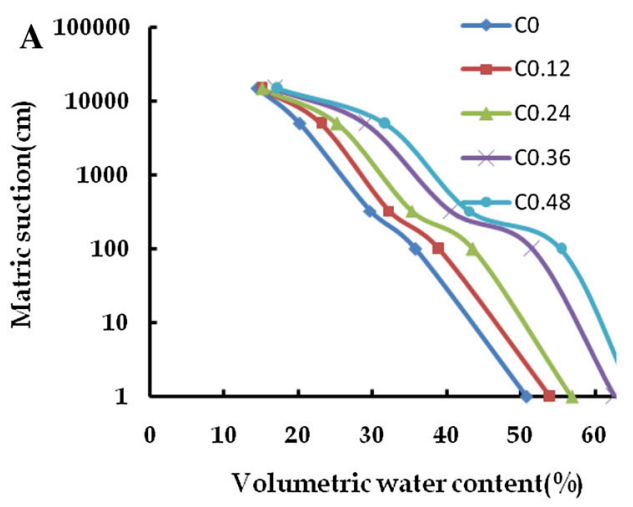

the PAWC in both types of soil, but the amount of PAWC increment in silty clay soil was greater than this increment in loamy sand soil, so that PAWC enhanced from $15.1 \%$ in $C_{0}$ (as control treatment of silty clay soil) to $25.7 \%$ in highest $\mathrm{CR}$ application rate $\left(C_{0.48}\right)$, and this means an increase of more than 10 percent of PAWC compared to the control. In terms of availability of soil water for plants, adding CR particles in clay soils with very fine pores leads to the improvement of the availability of soil water for plants. For loamy sand soil, the maximum amount of PAWC is related to $S_{0.48}$ treatment and it was $5.45 \%$ and a difference with the control $\left(S_{0}\right)$ is measured about $3 \%$. These results confirmed that the CR addition in soil could improve pore size distribution and helped to increase the plant-available water content.

\section{Relative water capacity $(R W C)$}

Another indicator that shows the status of availability of soil water for plants is relative water capacity (RWC) index. Relative water capacity is obtained from the ratio of

Table 4 Different soil water retention curve indices based on varying magnitudes of added crumb rubber

\begin{tabular}{llll}
\hline Treatment & PAWC $(\%)$ & AC $(\%)$ & RWC $(\%)$ \\
\hline $\mathrm{S}_{0}$ & $2.08 \pm 7.02^{\mathrm{d}}$ & $21.96 \pm 5.65^{\mathrm{b}}$ & $0.26 \pm 7.17^{\mathrm{c}}$ \\
$\mathrm{S}_{0.12}$ & $2.99 \pm 0.5^{\mathrm{c}}$ & $23.02 \pm 1^{\mathrm{b}}$ & $0.28 \pm 0.02^{\mathrm{bc}}$ \\
$\mathrm{S}_{0.24}$ & $3.50 \pm 0.67^{\mathrm{bc}}$ & $23.45 \pm 1.06^{\mathrm{ab}}$ & $0.29 \pm 0.01^{\mathrm{bc}}$ \\
$\mathrm{S}_{0.36}$ & $4.18 \pm 0.75^{\mathrm{b}}$ & $23.71 \pm 1.09^{\mathrm{ab}}$ & $0.31 \pm 0.02^{\mathrm{b}}$ \\
$\mathrm{S}_{0.48}$ & $5.45 \pm 0.9^{\mathrm{a}}$ & $25.07 \pm 1.1^{\mathrm{a}}$ & $0.35 \pm 0.02^{\mathrm{a}}$ \\
$C_{0}$ & $15.15 \pm 7.16^{\mathrm{e}}$ & $21.16 \pm 2.93^{\mathrm{a}}$ & $0.58 \pm 7.53^{\mathrm{c}}$ \\
$C_{0.12}$ & $17.12 \pm 1^{\mathrm{d}}$ & $21.83 \pm 2^{\mathrm{a}}$ & $0.59 \pm 0.02^{\mathrm{c}}$ \\
$C_{0.24}$ & $20.13 \pm 1.39^{\mathrm{c}}$ & $21.65 \pm 1.82^{\mathrm{a}}$ & $0.61 \pm 0.01^{\mathrm{bc}}$ \\
$C_{0.36}$ & $23.62 \pm 2.33^{\mathrm{b}}$ & $22.16 \pm 1.75^{\mathrm{a}}$ & $0.64 \pm 0.02^{\mathrm{ab}}$ \\
$C_{0.48}$ & $25.74 \pm 3.44^{\mathrm{a}}$ & $22.26 \pm 1.74^{\mathrm{a}}$ & $0.65 \pm 0.03^{\mathrm{a}}$ \\
\hline$A W C$ &
\end{tabular}

$A W C$ available water content, $A C$ air capacity, $R W C$ relative water content

The same letters in each group indicate no significant differences according to Duncan's Multiple Range Tests soil moisture at field capacity to soil saturation water content. These results indicated that CR affects the RWC in both soils significantly (Table 4).

\section{Air capacity (AC)}

The plant root needs both air and water simultaneously to survive. That portion of the soil porosity which is occupied by air is called the air capacity (AC). So soil air capacity index is one of the important indices for plant growth and its survival.

The volumetric difference between field capacity $\left(\theta_{\mathrm{fc}}\right)$ and water saturated point $\left(\theta_{\mathrm{s}}\right)$ considered as soil air capacity which both of these parameters (e.g. $\theta_{\mathrm{fc}}$ and $\theta_{\mathrm{s}}$ ) are acquired from soil moisture characteristics curve. Based on statistical analysis, increasing the amount of CR in the loamy sand substrates significantly $(p<0.05)$ increased air capacity, while it did not have any effect on silty clay soil (Table 4).

\section{Conclusion}

Soil organic matter is considered as the main factor of soil quality. Soil organic matter deficit is the most common problem in arid and semi-arid soils. In this study, amending two soils with distinct texture with different rates of crumb rubber modified some hydro-physical and chemical properties of soils.

Our results indicated that the application of CR has significant effect on decreasing the amount of soil compaction index (based on decreasing of bulk density and penetration resistance) and increasing volumetric water content at different suction points so that adding crumb rubber modified the water retention curve coefficients. Increasing plant-available water content (especially in silty clay soil) and soil relative water content are the examples of the positive impact of the crumb rubber application as a modifier. 
According to different studies, the micronutrient deficits are very common in calcareous soils of arid and semi-arid regions like Iran. The results of this study showed that the addition of crumb rubber can be a good source of microelements, especially for zinc.

In general, the results of this research proved positive impact of crumb rubber particles on various soil properties. Since this research was carried out in controlled greenhouse conditions and for limited incubation time, it is recommended that the effect of adding crumb rubber particles be evaluated in field condition and for longer times.

Open Access This article is distributed under the terms of the Creative Commons Attribution 4.0 International License (http://creative commons.org/licenses/by/4.0/), which permits unrestricted use, distribution, and reproduction in any medium, provided you give appropriate credit to the original author(s) and the source, provide a link to the Creative Commons license, and indicate if changes were made.

\section{References}

Abdelfattah MA (2013) Pedogenesis, land management and soil classification in hyper-arid environments: results and implications from a case study in the United Arab Emirates. Soil Use Manag 29:279-294. doi:10.1111/sum.12031

Adrover M, Moyà G, Vadell J (2017) Seasonal and depth variation of soil chemical and biological properties in alfalfa crops irrigated with treated wastewater and saline groundwater. Geoderma 286:54-63. doi:10.1016/j.geoderma.2016.10.024

Asadollah zadeh MJ (2013) Effect of microbial inoculation and endophyte symbiosis on the Zinc ( $\mathrm{Zn}$ ) release from worn out crumb rubber and its uptake by plant. M.Sc. thesis Soil Science, Faculty of Agriculture, Isfahan University of Technology

Bhatt B, Chandra R, Ram S, Pareek N (2016) Long-term effects of fertilization and manuring on productivity and soil biological properties under rice (Oryza sativa)-wheat (Triticum aestivum) sequence in Mollisols. Arch Agron Soil Sci 62(8):1109-1122. doi:10.1080/03650340.2015.1125471

Bhattacharjya S, Chandra R, Pareek N, Raverkar KP (2016) Biochar and crop residue application to soil: effect on soil biochemical properties, nutrient availability and yield of rice (Oryza sativa L.) and wheat (Triticum aestivum L.). Arch Agron. Soil Sci 62(8):1095-1108. doi:10.1080/03650340.2015.1118760

Bidaki SMY, Hajabbasi MA, Khoshgoftarmanesh AH, Eshghizadeh HR (2012) Effect of waste tire rubber particles on some chemical properties of a calcareous soil. J Sci Technol Agric Nat Resour Water Soil Sci 16(59):101-115

Blake GR, Hartge KH (1986) Methods of Soil Analysis. Part 1Physical and mineralogical methods, vol 9, 2nd edn. Agronomy Monograph. ASA and SSSA, Madison, pp 363-375

Calero N, Barron V, Torrent J (2008) Water dispersible clay in calcareous soils of southwestern Spain. Catena 74:22-30. doi:10. 1016/j.catena.2007.12.007

Chaney K, Shift RS (1984) The influence of organic matter on aggregate stability in some British soils. Soil Sci 35:223-230. doi:10.1111/j.1365-2389.1984.tb00278.x

Chaudhuri PS, Paul TK, Dey A, Datta M, Dey SK (2016) Effects of rubber leaf litter vermicompost on earthworm population and yield of pineapple (Ananas comosus) in West Tripura, India. Int J Recycl Org Waste Agric 5:93-103. doi:10.1007/s40093-0160120-z
Cornelis WM, Ronsyn J, Van Meirvenne M, Hartmann R (2001) Evaluation of pedotransfer functions for predicting the soil moisture retention curve. Soil Sci Soc Am J 65:638-648. doi:10. 2136/sssaj2001.653638x

Courtney R, Harrington T (2012) Growth and nutrition of Holcuslanatus in bauxite residue amended with combinations of spent mushroom compost and gypsum. Land Degrad Dev 23:144-149. doi:10.1002/ldr.1062

Dotaniya ML, Datta SC, Biswas DR, Dotaniya CK, Meena BL, Rajendiran S, Regar KL, Lata M (2016) Use of sugarcane industrial by-products for improving sugarcane productivity and soil health. Int J Recycl Org Waste Agric 5:185-194. doi:10. 1007/s40093-016-0132-8

Emami H, Astaraei AR, Fotovat A, Khotabaei M (2014) Effect of soil conditioners on cation ratio of soil structural stability, structural stability indicators in a sodic soil, and on dry weight of Maize. Arid Land Res Manag 28(3):325-339. doi:10.1080/15324982. 2013.856357

FAO (2012) Country report on history and status of soil survey in Iran. GSP regional workshop Jordan, Amman 1-5 April 2012. http://www.fao.org/fileadmin/user_upload/GSP/docs/Presenta tion_NEMA_Inception/The_Islamic_Republic_of_Iran_2.pdf

Faust S, Hanisch S, Buerkert A, Joergensen RG (2015) Soil properties under manured Tamarindus indica in the littoral plain of southwestern Madagascar. Arid Land Res Manag 29(2):167-179. doi:10.1080/15324982.2014.944243

Gee GW, Bauder JW (1986) Particles size analysis. In: Kelute A (ed) Methods of soil analysis. Part 1. Physical and mineralogical methods. Soil Sci Soc Am J. Agronomy Monograph 9. 2nd edn, pp. 383-411

Ghavibazoo A, Abdelrahman M (2013) Composition analysis of crumb rubber during interaction with asphalt and effect on properties of binder. Int J Pavement Eng 14(5):517-530. doi:10. 1080/10298436.2012.721548

Groenevelt PH, Grunthal PE (1998) Utilisation of crumb rubber as a soil amendment for sport turf. Soil Tillage Res 47:169-172. doi:10.1016/S0167-1987(98)00089-0

Huettermann A, Orikiriza LJB, Agaba H (2009) Application of superabsorbent polymers for improving the ecological chemistry of degraded or polluted lands. Clean Soil Air Water 37:517-526. doi: $10.1002 /$ clen. 200900048

Institute SAS (1996) SAS user's guide: statistics. SAS Institute Inc., Cary

Jalali V, Asadi-Kapourchal S, Homaee M (2017) Evaluating performance of macroscopic water uptake models at productive growth stages of durum wheat under saline conditions. Agric Water Manag 180:13-21. doi:10.1016/j.agwat.2016.10.015

Khoshgoftarmanesh AH, Eshghizadeh HR, Chaney RL (2012) Using acid-washed shredded waste-tire rubber in soilless media for tomato production. J Plant Nutr 35(9):1341-1348. doi:10.1080/ 01904167.2012.684126

Lia R, Tao R, Ling N, Chu G (2017) Chemical, organic and biofertilizer management practices effect on soil physicochemical property and antagonistic bacteria abundance of a cotton field: implications for soil biological quality. Soil Tillage Res 167:30-38. doi:10.1016/j.still.2016.11.001

Masowa MM, Kutu FR, Shange PL, Mulidzi R, Vanassche FMG (2016) The effect of winery solid waste compost application on maize growth, biomass yield, and nutrient content under greenhouse conditions. Arch Agron Soil Sci 62(8):1082-1094. doi:10.1080/03650340.2015.1115018

Najim KB, Hall MR (2012) Mechanical and dynamic properties of self-compacting crumb rubber modified concrete. Constr Build Mater 27:521-530. doi:10.1016/j.conbuildmat.2011.07.013

Nyamangara J, Gotosa J, Mpofu SE (2001) Cattle manure effects on structural stability and water retention capacity of a granitic 
sandy soil in Zimbabwe. Soil Tillage Res 62:157-162. doi:10. 1016/S0167-1987(01)00215-X

O'Sullivan M (1992) Uniaxial compaction effects on soil physical properties in relation to soil type and cultivation. Soil Tillage Res 24:257-269. doi:10.1016/0167-1987(92)90091-O

Pandian K, Subramaniayan P, Gnasekaran P, Chitraputhirapillai S (2016) Effect of biochar amendment on soil physical, chemical and biological properties and groundnut yield in rainfed Alfisol of semi-arid tropics. Arch Agron Soil Sci 62(9):1293-1310. doi:10.1080/03650340.2016.1139086

Parihara CM, Yadavb MR, Jata SL, Singha AK, Kumara B, Pradhanb S, Chakrabortyb D, Jatc ML, Jatd RK, Saharawate YS, Yadava OP (2016) Long term effect of conservation agriculture in maize rotations on total organic carbon, physical and biological properties of a sandy loam soil in north-western Indo-Gangetic Plains. Soil Tillage Res 161:116-128. doi:10.1016/j.still.2016. 04.001

Park CH, Li X, Jia RL, Hur JS (2015) Effects of superabsorbent polymer on cyanobacterial biological soil crust formation in laboratory. Arid Land Res Manag 29(1):55-71. doi:10.1080/ 15324982.2014.928835

Pérez G, Vila A, Rincón L, Solé C, Cabeza LF (2012) Use of rubber crumbs as drainage layer in green roofs as potential energy improvement material. Appl Energy 97:347-354. doi:10.1016/j. apenergy.2011.11.051

Quevauviller Ph, Lachica M, Barahona E, Rauret G, Ure A, Gomez A (1996) Interlaboratory comparison of EDTA and DTPA procedures prior to certification of extractable trace elements in calcareous soil. Sci Total Environ 178:127-132. doi:10.1016/ 0048-9697(95)04804-9

Rajaie M, Tavakoly AR (2016) Effects of municipal waste compost and nitrogen fertilizer on growth and mineral composition of tomato. Int J Recycl Org Waste Agric 5:339-347. doi:10.1007/ s40093-016-0144-4

Reynolds WD, Drury CF, Yang XM, Fox CA, Tan CS, Zhang TQ (2007) Land management effects on the near-surface physical quality of a clay loam soil. Soil Tillage Res 96:316-330. doi:10. 1016/j.still.2007.07.003

Riggle D (1994) Finding markets for scrap tires: utilization options. Biocycle 35:41-55

Roper MM, Ward PR, Keulen AF, Hill JR (2013) Under no-tillage and stubble retention, soil water content and crop growth are poorly related to soil water repellency. Soil Tillage Res 126:143-150. doi:10.1016/j.still.2012.09.006

Sağlam M, Dengiz O (2017) Spatial variability of soil penetration resistance in an alluvial delta plain under different land uses in middle Black Sea Region of Turkey. Arch Agron Soil Sci 63(1):60-73. doi:10.1080/03650340.2016.1178386

Sivakumar Babu GL, Vasudevan AK, Haldar S (2008) Numerical simulation of fiber-reinforced sand behavior. Geotext Geomembr 26(2):181-188. doi:10.1016/j.geotexmem.2007.06.004

Smolders E, Degryse F (2002) Fate and effect of zinc from tire debris in soil. Environ Sci Technol 36:3706-3710. doi:10.1021/ es025567p

Taheri S, Khoshgoftarmanesh AH, Shariatmadari H, Chaney RL (2011) Kinetics of zinc release from ground tire rubber and rubber ash in a calcareous soil as alternatives to $\mathrm{Zn}$ fertilizers. Plant Soil 341(1-2):89-97. doi:10.1007/s11104-010-0624-7

Tormena CA, Da Silva AP, Libardi PL (1999) Soil physical quality of a Brazilian Oxisol under two tillage systems using the least limiting water range approach. Soil Tillage Res 52:223-232. doi:10.1016/S0167-1987(99)00086-0

Turcotte DL (1989) Fractals in geology and geophysics. Pure Appl Geophys 131(171-1):96

van Genuchten MTh (1980) A closed-form equation for predicting the hydraulic conductivity of unsaturated soils. Soil Sci Soc Am J 44:892-898

Vanini JT, Rogers JN (1995) Topdressing with crumb rubber from used tires in variation in a semi-arid catchment: implications for land and agricultural water management. Land Degrad Dev $25: 163-172$

Walkley A, Black IA (1934) An examination of digestion method for determining soil organic matter and a proposed modification of the chromic acid titration. Soil Sci 37:29-38

Weyers SL, Spokas KA (2014) Crop residue decomposition in Minnesota biochar-amended plots. Solid Earth 5:499-507. doi:10.5194/se-5-499-2014

Yazdanpanah N, Mahmoodabadi M, Cerdà A (2016) The impact of organic amendments on soil hydrology, structure and microbial respiration in semiarid lands. Geoderma 266:58-65. doi:10.1016/ j.geoderma.2015.11.032

Yilmaz A, Degirmenci N (2009) Possibility of using waste tire rubber and fly ash with Portland cement as construction materials. Waste Manag 29:1541-1546. doi:10.1016/j.wasman.2008.11. 002

Zhao S, Wang L, Duo L (2009) Effects of waste crumb rubber on medium characters and growth of Lolium perenne L. Pak J Bot 41(6):2893-2900

Zhao S, He T, Duo L (2011) Effects of crumb rubber waste as a soil conditioner on the nematode assemblage in a turfgrass soil. Appl Soil Ecol 49:94-98. doi:10.1016/j.apsoil.2011.06.011 